\title{
РОЗРОБКА МЕТОДИКИ ВИЗНАЧЕННЯ ЯКІСНОГО СКЛАДУ АМІНОКИСЛОТ У РІДКОМУ ЕКСТРАКТІ ЧЕБРЕЦЮ ПОВЗУЧОГО
}

Вступ. В останні роки суттєво зросла кількість досліджень, пов'язаних із вивченням таких біологічно активних речовин (БАР), як амінокислоти. Згідно з джерелами літератури, саме вони проявляють різнопланову фрармакологічну активність і, тим самим, виконують важливі фрункції в організмі людини. Зокрема, встановлено, що деякі амінокислоти проявляють протизапальну, імуномодулюючу, заспокійливу дію тощо. Тому доречно розглядати їх як перспективні БАР для створення нових лікарських засобів. Фармацевтична розробка на основі густого екстракту чебрецю повзучого (ЧП) та ефрірної олії чебрецю звичайного передбачала насамперед підбір оптимального способу одержання рідкого екстракту чебрецю повзучого, який отримували за технологією, що дозволила в короткий термін одержати максимальний витяг БАР і відтворити, відповідно, якісний склад досліджуваної сировини. При стандартизації трави чебрецю повзучого серед основних маркерів якості було обрано також амінокислоти, тому необхідно підтвердити їх якісний склад і в рідкому екстракті ЧП, що є невід'ємним етапом при проведенні стандартизації досліджуваного екстракту.

Мета дослідження - розробити методику визначення якісного складу амінокислот у рідкому екстракmі чебрецю повзучого та запропонувати відповідні маркери якості для проведення його стандартизації.

методи дослідження. Під час дослідження використано рідкий екстракт чебрецю повзучого, метод тонкошарової хроматографрії, стандартні зразки речовин: гліцину, глутамінової кислоти (“Sigma"), лейцину, тирозину, аланіну, аспарагінової кислоти ("Fluka"), хроматографрічні пластинки "Silica gel $F_{254}$ " фрірми "Merck", прилад для автоматичного нанесення проб на пластинку “CAMAG Linomat 5", хроматографрічну камеру "GAMAG", сушильну шасру.

Результати й обговорення. Для стандартизації рідкого екстракту ЧП необхідно прослідкувати можливість ідентифрікації його основних БАР, продовжуючи запропонований підхід: трава чП - рідкий екстракт - густий екстракт - готовий лікарський засіб. Ідентифрікацію амінокислот у рідкому екстракті ЧП проводили в системі розчинників ізопропанол $P$ - мурашина кислота $P$ - вода $P$ у співвідношенні 40:2:10 фрармакопейним методом аналізу - тонкошаровою хроматографрією висхідним способом. Для розробки цієї методики вивчали різні системи розчинників, способи та умови хроматографування, в результаті чого було підібрано оптимальну систему розчинників із хорошою розділювальною здатністю.

Висновки. Розроблено методику визначення якісного складу амінокислот у рідкому екстракті чебрецю повзучого. Під час цього експерименту ідентифріковано 6 амінокислот і запропоновано відповідні маркери якості для проведення стандартизації досліджуваного екстракту.

КЛЮЧОВІ СЛОВА: трава; чебрець повзучий; рідкий екстракт; ідентифрікація; тонкошарова хроматографрія; амінокислоти.

ВСТУП. Після проведення аналізу літератури було встановлено, що чебрець повзучий (ЧП) $€$ перспективним джерелом для розробки нових вітчизняних препаратів з лікарської рослинної сировини (ЛРС) для лікування патологій верхніх дихальних шляхів [1-3]. Оскільки ЧПє рослиною, яка містить складний комплекс біологічно активних речовин (БАР), серед яких значну частку займають амінокислоти, яким властива різнопланова фрармакологічна активність [4, 5]. Під

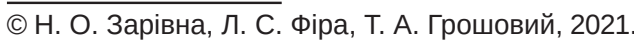

час попередніх наших досліджень проаналізовано ЛРС ЧП [6] та підтверджено значний вміст амінокислот. Створення фрармакологічного препарат на основі густого екстракту чебрецю повзучого та ефрірної олії чебрецю звичайного передбачало насамперед розробку технології одержання рідкого екстракту ЧП, який отримували оптимальним способом [7], що дозволив одержати рідкий екстракт з максимальним та стабільним вмістом біологічно активних речовин ЛРС чебрецю повзучого [6, 7], тому до- 
речне їх поглиблене вивчення і в одержаному екстракті.

Мета дослідження - розробити методику визначення якісного складу амінокислот у рідкому екстракті чебрецю повзучого та запропонувати відповідні маркери якості для проведення його стандартизації.

МЕТОДИ ДОСЛІДЖЕННЯ. Об'єкТом ДОслідження був рідкий екстракт чебрецю повзучого. Для проведення аналізу використовували метод тонкошарової хроматографрії із застосуванням хроматогр асрічних пластинок "Silica gel $F_{254}$ " фрірми "Merck", приладу "CAMAG Linomat 5" (для нанесення проб), хроматографрічної камери "GAMAG" і стандартних зразків речовин: гліцину, глутамінової кислоти ("Sigma”), лейцину, тирозину, аланіну, аспарагінової кислоти ("Fluka").

РЕЗУЛЬТАТИ Й ОБГОВОРЕННЯ. ЯКіСНИЙ склад амінокислот у рідкому екстракті чП визначали із застосуванням сучасного фрармакопейного, селективного та чутливого методу аналізу [8]. При розробці цієї методики ми вивчали різні способи й умови хроматографрування [8], кількість нанесення проби, а також спосіб проявлення та час хроматографрування. У результаті було підібрано оптимальну систему розчинників 3 най кращою розділювальною здатністю ізопропанол P - мурашина кислота Р - вода Р у співвідношенні 40:2:10. Для проведення тонкошарової хроматограсрії використовували пластинки "Silica gel $F_{254}$ " ("Merck", Німеччина) та експериментально підібрану систему розчинників із застосуванням розчину стандартних зразків відповідних амінокислот. Хроматограми проявляли розчином нінгідрину Р у суміші кислоти оцтової Р і бутанолу Р.

Нижче наведено розроблену й адаптовану нами методику ідентифрікації амінокислот у досліджуваному екстракті чебрецю повзучого.

Методика ідентифрікації амінокислот у рідкому екстракті чебрецю повзучого.

Випробовуваний розчин: рідкий екстракт чебрецю повзучого.

Розчин порівняння: 10 мг стандартних зразків гліцину, лейцину, тирозину, аланіну, аспарагінової і глутамінової кислот розчиняють у 25 мл води P.

На лінію старту хроматографрічної пластинки "Silica gel $\mathrm{F}_{254}$ " розміром 20×20 см із товщиною шару 0,25 мм наносять смугами завдовжки 10 мм 20 мкл випробовуваного розчину та 5 мкл розчину порівняння. Пластинку сушать на повітрі впродовж 30 хв, поміщають у камеру з рухомою фразою ізопропанол P - мурашина кислота $P$ вода $P$ (40:2:10) і хроматографрують висхідним способом. Коли фрронт розчинників пройде 15 см від лінії старту, ії̈ виймають з камери і сушать на повітрі. Пластинку обприскують розчином нінгідрину Р у суміші кислоти оцтової Р і бутанолу $P$, нагрівають при температурі $100-105^{\circ} \mathrm{C}$ 3-5 хв і проглядають при денному світлі.

На хроматограмах випробовуваного розчину рідкого екстракту спостерігали зони тирозину, аланіну, лейцину, гліцину, глутамінової та аспарагінової кислот на рівні відповідних зон на хроматограмі розчину порівняння.

Схему хроматограми, яку отримано при дослідженні рідкого екстракту чебрецю повзучого за умов ідентифрікації амінокислот, наведено на рисунку.

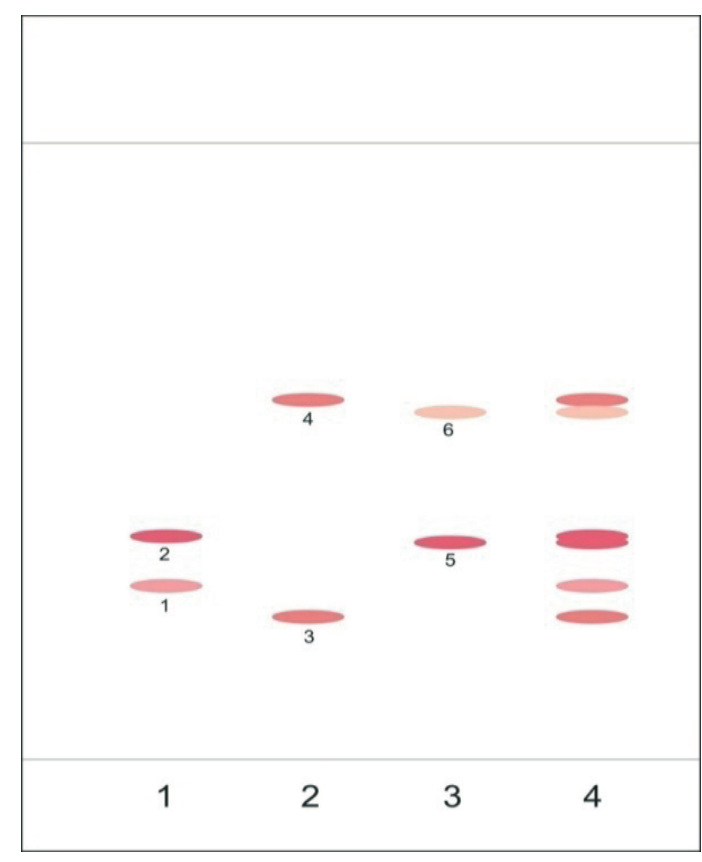

Рис. Схема хроматограми випробовуваного розчину (4) та розчинів порівняння $(1,2,3)$, на яких 1 - гліцин; 2 - аланін; 3 - аспарагінова кислота; 4 - лейцин; 5 - глутамінова кислота; 6 - тирозин.

У результаті проведеного хроматограсрічного дослідження ми ідентифікували 6 амінокислот: гліцин, аланін, аспарагінову кислоту, лейцин, глутамінову кислоту, тирозин, які повністю за кольором зон та фракторами рухливості збігаються з відповідними зонами стандартних зразків. Це вказує на коректність підібраних умов хроматограсрування та відповідного способу одержання рідкого екстракту, що дозволило отримати відтворювані БАР досліджуваної ЛРС.

Таким чином, можна запропонувати обрати ідентиорікаційними маркерами якості рідкого екстракту ЧП вищевказані амінокислоти, з яких переважає гліцин.

Для проведення стандартизації рідкого екстракту ЧП, крім запропонованих маркерів якості, 
необхідно також визначити кількісний вміст цих БАР і обрати відповідні критерії прийнятності, що буде наступним етапом наших досліджень.

ВИСНОВКИ. 1. Розроблено й апробовано методику визначення якісного складу амінокислот у рідкому екстракті чебрецю повзучого.

\section{СПИСОК ЛІТЕРАТУРИ}

1. Thyme oil. Monograph N: 1374 . Concerned also monograph N 865 (Thymi herba) and N 1891 (Serpylli herba). - PA/PH/ Exp. 13A/T (09) 351 R. - Strasbourg: European Department for the Quality of Medicines, April 2009.

2. Соколов С. Я. Фитотерапия и фитофрармакология : руководство для врачей / С. Я. Соколов. - М. : МИА, 2000. - 976 c.

3. Thyme: The genus Thymus. London, New York: Taylor, Fransis. - 2002. - 330 p.

4. Зарівна Н. О. Вивчення амінокислотного складу трави Thymus Serpyllum / Н. О. Зарівна // Укр. біофрармац. журн. - 2014. - № 3 (32). - С. 67-70.

5. Борисова Д. А. Аминокислоты сырья первоцвета лекарственного / Д. А. Борисова // Фармация. 2011. - № 8. - C. 11-13.

\section{REFERENCES}

1. (2009). Thyme oil. Monograph N: 1374. Concerned also monograph N 865 (Thymi herba) and N 1891 (Serpylli herba). PA/PH/ Exp. 13A/T (09) 351 R. Strasbourg: European Department for the Quality of Medicines.

2. Sokolov, S.Ya. (2000). Fitoterapiya i fitofarmakologiya: rukovodstvo dlya vrachey [Phytotherapy and phytopharmacology: A guide for doctors]. Moscow: MIA [in Russian].

3. (2002). Thyme: The genus Thymus. London, New York: Taylor, Fransis.

4. Zarivna, N.O. (2014). Vyvchennia aminokyslotnoho skladu travy Thymus Serpyllum [Study of the amino acid composition of the herb Thymus Serpyllum]. Ukrainskyi biofarmatsevtychnyi zhurnal - Ukrainian Biopharmaceutical Journal, 3 (32), 67-70 [in Ukrainian].

5. Borysova, D.A. (2011). Aminokysloty syrya pervotsveta lekarstvennogo [Amino acids of raw primrose
2. Запропоновано ідентифрікаційні маркери рідкого екстракту чебрецю повзучого (гліцин, аланін, аспарагінову кислоту, лейцин, глутамінову кислоту, тирозин) для проведення його стандартизації.
6. Амінокислотний і мінеральний склад листя та лушпиння плодів гледичії звичайної / М. А. Дученко, О. В. Демишко, С. В. Ковальов [та ін.] // Вісн. фрармації. - 2010. - № 2 (62). - С. 42-45.

7. Пат. 73543 Україна, МПК ${ }^{51}$ C 11 В 1/10, А 61 К 9/08, А 61 K 35/00. Спосіб отримання рідкого екстракту чебрецю повзучого / Н. О. Зарівна, Л.В.Вронська, Т. А. Грошовий ; заявник і патентовласник Терноп. держ. мед. ун-т імені І. Я. Горбачевського. - Заявл. 26.03.12 ; опубл. 25.09.12, Бюл. №18.

8. Державна Фармакопея України : в 3 т. / Державне підприємство "Український науково-експертний фрармакопейний центр якості лікарських засобів". 2-ге вид. - Харків : Державне підприємство "Український науково-експертний фрармакопейний центр якості лікарських засобів", 2015. - Т. 1 - 1128 с. medicinal]. Farmatsiya - Pharmacy, 8, 11-13 [in Ukrainian].

6. Duchenko, M.A., Demyshko, O.V., \& Kovalov, S.V. (2010). Aminokyslotnyi i mineralnyi sklad lystia ta lushpynnia plodiv hledychii zvychainoi [Amino acid and mineral composition of leaves and peel of the fruit of St. John's wort]. Visnyk farmatsii - Bulletin of Pharmacy, 2 (62), 42-45 [in Ukrainian].

7. Zarivna, N.O., Vronska, L.V., \& Hroshovyi, T.A. (2012). Pat. Ukrainy, Sposib otrymannia ridkoho ekstraktu chebretsiu povzuchoho [The method of obtaining liquid creeping thyme extract]. No. 73543 MPK51 S $11 \mathrm{~V} 1 / 10$, A $61 \mathrm{~K} \mathrm{9/08,} \mathrm{A} 61$ K 35/00; Biul. №18 [in Ukrainian].

8. (2015). Derzhavna Farmakopeia Ukrainy: $v 3 t$. [State Pharmacopoeia of Ukraine: in 3 vol.]. Kharkiv: State Enterprise "Ukrainian Scientific Pharmacopoeia Center for the Quality Medicines" [in Ukrainian]. 


\section{DEVELOPMENT OF A METHODOLOGY FOR DETERMINING THE QUALITATIVE COMPOSITION OF AMINO ACIDS IN CREEPING THYME LIQUID EXTRACT}

\section{Summary}

Introduction. In recent years, the number of studies related to the study of such biologically active substances as amino acids has increased significantly. According to the sources of literature, they show diverse pharmacological activity and thereby perform important functions in the human body. In particular, it has been found that some amino acids exhibit anti-inflammatory, immunomodulatory, soothing activity, etc. Therefore, it is appropriate to consider them as promising BAS for the creation of new medicines. Pharmaceutical development on the basis of thick extract of creeping thyme and thyme essential oil of ordinary provided, first of all, the selection of the optimal method of obtaining the creeping thyme liquid extract (CT), which was obtained using the technology, which allowed in a short time to obtain the maximum extract of BAS and reproduce, accordingly, the qualitative composition of the raw materials under investigation. Since, when standardizing creeping thyme herb, among the main quality markers, amino acids were also chosen, so it is necessary to confirm their quality composition in the liquid extract of CT, which is an integral stage in the standardization of the extract under study.

The aim of the study - to develop a methodology for determining the quality composition of amino acids in liquid CT extract and offer appropriate quality markers for its standardization.

Research Methods. Creeping thyme liquid extract, standard samples: glycine, glutamic acid (Sigma), leucine, tyrosine, alanine, aspartic acid (Fluka), fine-layer chromatography (TLC), Silica gel F254 chromatographic plates of "Merck", device for automatic application of samples on the plate "CAMAG Linomat 5", chromatographic camera "GAMAG", dryer.

Results and Discussion. To standardize creeping thyme liquid extract, it is necessary to monitor the possibility of identifying the main creeping thyme BAS, continuing the proposed approach: creeping thyme herb - liquid extract - thick extract - finished medicinal product. Identification of amino acids in CT liquid extract was carried out in the solvent system: isopropanol $R$ - formic acid $R$ - water $R$ in the ratio (40:2:10) by pharmacopoeia analysis method - thin-layer chromatography ascending method. To develop this technique, various solvent systems, methods and conditions of chromatography were studied, as a result of which the optimal solvent system with good separating ability was selected.

Conclusions. The method of determining the qualitative composition of amino acids in creeping thyme liquid extract has been developed. As a result of this experiment, six amino acids were identified and appropriate quality markers were proposed for standardization of the extract under study.

KEY WORDS: creeping thyme herb; thyme creeping; liquid extract; identification; thin layer chromatography; amino acids.

Отримано 01.07.21

Адреса для листування: Н. О. Зарівна, Тернопільський національний медичний університет імені І. Я. Горбачевського мОз України, майдан Волі, 1, Тернопіль, 46001, Україна, e-mail: zarivna@tdmu.edu.ua. 